\title{
Dampak Thin Capitalization, Profitabilitas, Dan Ukuran Perusahaan Terhadap Tindakan Penghindaran Pajak
}

\author{
Tesa Anggraeni ${ }^{1}$, Rachmawati Meita Oktaviani ${ }^{2}$ \\ ${ }^{1,2}$ Fakultas Ekonomika dan Bisnis/Akuntansi, Universitas Stikubank Semarang \\ *Email korespondensi: anggraeniang23@gmail.com
}

\begin{abstract}
This researcher examines how thin capitalization, profitability, and company size affect tax avoidance. The sample used is manufacturing companies listed on the Indonesia Stock Exchange for the period 2017 to 2019. The sampling method uses purposive sampling in order to obtain 69 manufacturing companies. This study uses panel data regression analysis techniques with the help of the Eviews 10. This study shows that the independent variable thin capitalization has no effect on tax avoidance. While profitability has a significant positive effect on tax avoidance, and company size has a significant negative effect on tax avoidance.
\end{abstract}

Keywords : Tax Avoidance, Thin Capitalization, Profitability, Company Size

Saran sitasi: Anggraeni, T., \& Oktaviani, R. M. (2021). Dampak Thin Capitalization, Profitabilitas, Dan Ukuran Perusahaan Terhadap Tindakan Penghindaran Pajak. Jurnal Akuntansi dan Pajak, 21 (2), 390-397. doi:http://dx.doi.org/10.29040/jap.v21i2.1530

DOI: http://dx.doi.org/10.29040/jap.v21i2.1530

\section{PENDAHULUAN}

Pajak memiliki kedudukan yang sangat kuat untuk kemajuan suatu negara. Di Indonesia, lebih dari $80 \%$ penerimaan negara Republik Indonesia berasal dari pajak.Pada tahun 2019 pajak di Indonesia mengalami penurunan khususnya dibidang industri manufaktur sebesar Rp. 16,77 triliun atau turun 16,2\% year on year. Padahal sektor ini berkontribusi sebesar $20,8 \%$ terhadap penerimaan pajak. Meski sektor manufaktur masih tumbuh negatif, tetapi penerimaan pajak sektor lainnya masih tumbuh positif bahkan meningkat signfikan dibandingkan tahun lalu. Kementrian Keuangan mencatat penerimaan pajak sepanjang Januari 2019 tumbuh 8,82\% atau meningkat dari Rp 79 triliun menjadi Rp 86 triliun.

Penurunan tingkat penerimaan pajak tersebut disebabkan oleh wajib pajak badan yang menimimumkan beban pajaknya untuk memaksimalkan laba perusahaan. Penghindaran pajak yang dilakukan menggunakan strategi-strategi dibidang perpajakan.

Dalam melakukan penghindaran pajak terdapat beberapa faktor yang dapat mempengaruhinya, diantaranya yaitu thin capitalization, profitabilitas, dan ukuran perusahaan. Thin capitalization merupakan mekanisme merujuk pada keputusan investasi oleh perusahaan dalam mendanai operasi bisnis dengan mengutamakan pendanaan hutang dibandingkan menggunakan modal ekuitas dalam struktur modalnya (Salwah \& Herianti, 2019). Banyak perusahaan yang lebih memilih menggunakan cara thin capitalization agar dapat terhindar dari pajak karena perusahaan lebih memilih untuk membayar bunga pinjaman daripada membayarkan pajak. Bunga pinjaman tersebut akan menjadi beban yang dapat dikurangkan sebagai pengurang pajak. Dengan demikian pajak yang dibayarkan oleh perusahaan semakin sedikit.

Di Indonesia, aturan mengenai thin capitalization telah diatur dalam Undang-Undang khususnya yang berkaitan dengan rasio hutang terhadap modal. Pendekatan rasio hutang dan modal diatur dalam Pasal 18 ayat (1) Undang-Undang Pajak Penghasilan dimana Menteri Keuangan berwenang menentukan besaran perbandingan hutang dengan modal yang dapat dibenarkan untuk kepentingan penghitungan pajak. Besarnya perbandingan antara hutang dan modal sesuai dengan Peraturan Menteri Keuangan No.169/ PMK.010/2015 tentang Penentuan Besarnya 
Perbandingan antara hutang dan modal perusahaan untuk Keperluan Penghitungan Pajak Penghasilan ditetapkan paling tinggi sebesar empat dibanding satu (4:1) (Salwah \& Herianti, 2019).

Wati \& Utomo (2020), dan Olivia \& Dwimulyani (2019) menyebutkan bahwa bahwa thin capitalization tidak memiliki pengaruh yang signifikan, dapat diartikan bahwa thin capitalization secara individu tidak berpengaruh terhadap penghindaran pajak. Peneliti Salwah \& Herianti, (2019); Jumailah, (2020) dan Widodo et al., (2020) bahwa thin Capitalization berpengaruh positif terhadap penghindaran pajak. Peningkatan praktik thin Capitalization menyebabkan tindakan penghindaran pajak akan mengalami peningkatan. Pembiayaan berupa utang akan memunculkan biaya bunga, di mana biaya bunga merupakan unsur pengurang dalam proses perhitungan penghasilan kena pajak. Sedangkan pembiayaan perusahaan berupa modal saham akan muncul dividen di mana dividen bukan unsur pengurang untuk penghasilan kena pajak.

Profitabilitas merupakan salah satu cara menunjukkan kemampuan suatu perusahaan dalam menghasilkan laba selama periode tertentu pada tingkat penjualan, asset, dan modal saham tertentu. Rasio profitabilitas diproksikan dalam Return On Assets (ROA). ROA berfungsi untuk mengukur efektivitas perusahaan dalam menggunakan sumberdaya yang dimilikinya. Semakin tinggi profitabilitas perusahaan akan semakin tinggi pula laba bersih perusahaan yang dihasilkan. Teori agensi memacu para agent untuk meningkatkan laba perusahaan. Ketika laba yang diperoleh perusahaan membesar, maka jumlah pajak penghasilan akan meningkat sesuai dengan peningkatan laba perusahaan (Jamaludin, 2020).

Hutapea \& Herawaty (2020),Saputra et al., (2019), dan Olivia \& Dwimulyani (2019), menyatakan bahwa profitabilitas berpengaruh positif terhadap tax avoidance. Semakin efisien perusahan maka pajak yang dibayar akan lebih sedikit sehingga tarif pajak efektif perusahaan menjadi lebih rendah. Tarif pajak efektif perusahaan yang rendah merupakan proksi tingkat penghindaran pajak yang tinggi. Namun pernyataan ini bertolak belakang dengan penelitian yang dilakukan oleh Jamaludin (2020) pengaruh profitabilitas (Return On Assets) terhadap penghindaran pajak menunjukkan bahwa profitabilitas (Return On Assets) berpengaruh negatif dan tidak signifikan terhadap tax avoidance. Dwiyanti
\& Jati, (2019) menyatakan bahwa profitabilitas berpengaruh negatif signifikan terhadap penghindaran pajak.

Ukuran perusahaan juga merupakan faktor yang berpengaruh terhadap kegiatan penghindaran pajak. Hal ini karena digambarkan dengan semakin besar perusahaan semakin besarsumber daya yang dimiliki dengan harapan dapat mengelola pajak dengan baik. Hal ini dilakukan dengan cara memanfaatkan beban penyusutan dan amortisasi yang timbul dari pengeluaran untuk memperoleh aset.Beban penyusutan dan amortisasi dapat digunakan sebagai pengurang penghasilan kena pajak perusahaan (Putri, 2018).

Wulandari \& Masqudi (2019) menyatakan bahwa ukuran peusahaan berpengaruh positif dan tidak signifikan terhadap penghindaran pajak. Putri (2018) dan Sutono (2020), menyatakan bahwa ukuran perusahaan berpengaruh negatif dan signifikan terhadap penghindaran pajak.Putri et al., (2019) menyatakan bahwa ukuran perusahan berpengaruh negatif dan tidak signifikan terhadap penghindaran pajak. Hubungan yang negatif antara ukuran perusahaan ini mengindikasikan bahwa perusahaan dengan sekala besar akan lebih cenderung melaporkan kondisi perusahaannya lebih spesifik dan akurat. Hal ini membuat para manajer yang ada di perusahaan besar tidak memiliki kesempatan yang lebih kecil dibandingkan perusahaan yang berskala kecil dalam memanipulasi pendapatan labanya.

\section{Teori Agensi}

Teori Agensi atau Teori keagenan menurut Jensen dan Meckling (1976) adalah suatu kontrak di bawah satu atau lebih yang melibatkan agen untuk melaksanakan beberapa layanan bagi mereka dengan melakukan pendelegasian wewenang pegambilan keputusan kepada agen. Teori Agensi menjelaskan hubungan antara pemilik perusahaan (Prinsipal) dan manajer (agen). Konflik agensi adalah konflik yang muncul antara pemilik, karyawan dan manajer perusahaan dimana ada kecenderungan manajer untuk mengutamakan individu tujuan daripada tujuan perusahaan. Konflik kepentingan bisa saja terjadi karena terdapat perbedaan kepentingan antar perusahaan pemilik dan pengelola sehingga dapat terjadi ketidakseimbangan informasi bahwa manajer memiliki informasi lebih lanjut tentang perusahaan dibandingkan dengan pemilik perusahaan (Oktaviani et al., 2019). 
Teori agensi dalam hubungannya dengan penghindaran pajak, para pemegang saham menginginkan manajemen mengatur laporan keuangan yang menguntungkan pemegang saham, sehingga manajemen melakukan cara dengan mengatur laba yang besar dengan beban pajak yang sekecil-kecilnya, sehingga cara penghindaran pajak yang dilakukan oleh manajemen dalam mengatur laporan keuangannya. Alokasi yang harusnya dibebankan untuk membayar pajak tidak dibayarkan seluruhnya karena manajemen mengatur pajaknya lebih rendah dari seharusnya. Alokasi yang sisa tersebut akan menjadi keuntungan bagi perusahaan (Andawiyah et al., 2019).

\section{Penghindaran Pajak}

Penghindaran pajak adalah upaya penghindaran pajak yang dilakukan secara legal dan aman bagi wajib pajak karena tidak bertentangan dengan ketentuan perpajakan, dimana metode dan teknik yang digunakan cenderung memanfaatkan kelemahankelemahan (grey area) yang terdapat dalam undangundang dan peraturan perpajakan itu sendiri, untuk memperkecil jumlah pajak yang terutang (Rejeki et al., 2019). Perusahaan memiliki alasan untuk melakukan penghindaran pajak, yaitu untuk mengurangi jumlah keuntungan dengan tidak mengakui pendapatan saat ini tetapi keberadaan diakui di masa depan. Karena semakin tinggi, semakin tegas laba yang dilaporkan, semakin tinggi beban pajaknya. Perilaku Penghindaran pajakdapat menimbulkan konflik keagenan antara kepentingan manajer dan kepentingan investor. Penghindaran pajak bisa meningkatkan perilaku oportunistik manajer, dengan mengenalibiaya pribadi menjadi biaya operasional perusahaan untuk mengurangikeuntungan yang diperoleh investor (Oktaviani et al., 2019).

\section{Thin Capitalization}

Thin capitalization adalah pembentukan struktur modal perusahaan dengan kombinasi kepemilikan hutang yang banyak dan modal yang kecil. Perusahaan dapat mengurangkan beban bunga, sehingga penghasilan kena pajak akan lebih kecil. Pengurangan seperti ini menyebabkan efek makro berupa berkurangnya potensi pendapatan negara dari pajak (Salwah \& Herianti, 2019).

\section{Profitabilitas}

Profitabilitas merupakan suatu ukuran dalam menilai kinerja perusahaan, yang dapat diukur dengan menggunakan berbagai rasio keuangan, salah satunya dengan Return on asset (ROA). ROA merupakan rasio yang mengukur pengembalian atas total aset dengan membandingkan laba bersih dengan total aset. ROA digunakan untuk mengukur kemampuan suatu perusahaan untuk menghasilkan laba atas aset yang dimilikinya. Semakin besar ROA semakin besar pula tingkat keuntungan yang dapat dicapai oleh perusahaan dan semakin efektif dan efisien kinerja perusahaan tersebut dari mengelola asset perusahaan (Olivia \& Dwimulyani, 2019).

\section{Ukuran Perusahaan}

Ukuran Perusahaan menunjukkan kemampuan perusahaan dengan tindakan pengembalian keputusan perpajakannya. Ukuran perusahaan menunjukkan kestabilan dan kemampuan perusahaan untuk melakukan aktivitas ekonominya. Semakin besar ukuran perusahaan maka semakin menjadi pusat perhatian dari pemerintah dan akan menimbulkan kecenderungan untuk berlaku patuh (compliances) atau menghindari pajak (tax avoidance) (Putri, 2018). Pengembangan Hipotesis

\section{Pengaruh thin capitalization terhadap penghindaran pajak}

Thin capitalization dapat menjadi masalah dalam perpajakan dikarenakan adanya perbedaan perlakuan antara investasi modal dan investasi utang. Pada investasi modal, pengembalian modal dalam bentuk dividen akan dikenakan pajak, sedangkan melalui pendanaan utang akan menimbulkan beban bunga yang dapat dijadikan sebagai pengurang penghasilan kena pajak. Perusahaan menggunakan teori agensi untuk kepentingan penghindaran pajak pada perusahaan. Maka dari itu banyak perusahaan yang memilih investasi hutang dengan membayar beban bunga, sehingga penghasilan kena pajak akan lebih kecil. (Wati \& Utomo, 2020); (Widodo et al., 2020); (Olivia \& Dwimulyani, 2019); (Falbo \& Firmansyah, 2018); (Jumailah, 2020). menyatakan bahwa thin capitalization berpengaruh positif terhadap penghindaran pajak. Semakin tinggi perusahaan memiliki utang untuk pembiayaan perusahaan maka, beban bunga akan semakin tinggi dan mengakibatkan tingginya penghindaran pajak yang dilakukan oleh perusahaan. Efek dari adanya Thin Capitalization ini berpengaruh makro ke negara, karena semakin banyak perusahaan menggurangi beban pajaknya akan semakin mengurangnya pendapatan negara melalui pajak. Dari penelitian tersebut, maka diambil hipotesis:

$\mathrm{H}_{1}$ : Thin capitalization diduga berpengaruh positif terhadap penghindaran pajak 


\section{Pengaruh profitabilitas terhadap penghindaran pajak}

Profitabilitas merupakan salah satu pengukuran bagi kinerja suatu perusahaan yang diukur dengan Return on assets (ROA). Rasio ROA menunjukkan bahwa besarnya laba yang diperoleh perusahaan dengan menggunakan total aset yang dimilikinya. Agency Theory akan memacu para agen untuk meningkatkan laba perusahaan sehingga jumlah pajak penghasilan akan meningkat sesuai dengan peningkatan laba perusahaan. Laba perusahaan yang diukur dengan rasio profitabilitas menunjukan kinerja dari manajemen,Apabila rasio profitabilitas tinggi, berarti menunjukkan adanya efisiensi yang dilakukan oleh pihak manajemen dan tindakan efisiensi tersebut mengurangi nilai efektif tax rate.(Hutapea \& Herawaty, 2020), (Saputra et al., 2019), (Olivia \& Dwimulyani, 2019) menyatakan bahwa profitabilitas berpengaruh positif terhadap penghindaran pajak. Berdasarkan dugaan diatas, maka peneliti mengambil hipotesis sebagai berikut :

\section{$\mathbf{H}_{2}$ : Profitabilitas diduga berpengaruh positif terhadap Penghindaran Pajak}

\section{Pengaruh ukuran perusahaan terhadap penghindaran pajak}

Ukuran perusahaan merupakan perbandingan skala yang mengukur besar atau kecilnya perusahaan berdasarkan aset. Aset merupakan kekayaan yang dimiliki oleh perusahaan yang digunakan sebagai proses bisnis atau pengelolaan bisnis yang dapat menghasilkan keuntungan. Besarnya aset dijadikan sebagai tolok ukur bagi prinsipal dalam melakukan kegaiatan investasi. Semakin besar perusahaan maka akan semakin meningkat juga jumlah produktifitas perusahaan tersebut. hal ini akan membuat laba perusahaan meningkat dan mempengaruhi tingkat pembayaran pajak. Perencanaan pajak bertujuan untuk meminimalisir beban pajak perusahaan, perusahaan dapat mengelola total aset perusahaan untuk mengurangi penghasilan kena pajak dengan cara memanfaatkan beban penyusutan dan amortisasi yang timbul dari pengeluaran untuk memperoleh aset tersebut. karena beban penyusutan dan amortisasi dapat digunakan sebagai pengurang penghasilan kena pajak perusahaan( Putri, 2018).

Penelitian yang dilakukan oleh Putri, (2018) dan Sutono, (2020) menyatakan bahwa ukuran perusahaan berpengaruh negatif signifikan terhadap penghindaran pajak.Peneliti menduga hipotesis sebagai berikut :
$\mathbf{H}_{3}$ : Ukuran perusahaan diduga berpengaruh positifsignifikan terhadap penghindaran pajak.

\section{METODE PENELITIAN}

Populasi, Sampel, dan Teknik Pengambilan Sampel

Dalam penelitian ini populasi yang diambil yang diambil adalah seluruh perusahaan manufaktur yang terdaftar di Bursa Efek Indonesia periode 2017-2019. Teknik samping yang digunakan adalah purposive sampling methode yaitu pemilihan berdasarkan karateristik dengan pemilihan sampel atas dasar kecocokan dengan pemilihan sampel yang telah ditentukan. Kriteria sampel dalam penelitian ini adalah sebagai berikut: a). perusahaan manufaktur yang terdaftar di Bursa Efek Indonesia periode 20172019 , b). perusahaan manufaktur yang mempublikasikan laporan keuangan periode 20172019 secara berturut-turut, c). mempunyai laba pada laporan keuangan periode 2017-2019, dan d). mempunyaidata secara lengkap berkaitan dengan variabel yang dilakukan peneliti selama periode penelitian tahun 2017-2019.

\section{Identifikasi Variabel}

Penelitian yang dilakukan ini menggunakan dua variabel sebagai berikut: a). variabel dependen (Y) adalah variabel yang menjadi akibat karena dipengaruhi oleh variabel independen. Pada penelitian ini variabel dependen yang digunakan adalah penghindaran pajak dan b). variabel independen (X) adalah variabel yang mempengaruhi atau menjadi sebab perubahan variabel dependen. Pada penelitian ini variabel independen yang digunakan adalah thin capitalization, profitabilitas, dan ukuran perusahaan.

\section{Definisi Operasional dan Pengukuran Variabel Penghindaran Pajak}

Penghindaran pajak menjadi salah satu bentuk perlawanan aktif wajib pajak yang banyak digunakan oleh wajib pajak dalam mengurangi beban pajak terhutang (Salwah \& Herianti, 2019).

$$
\text { ETR }=\frac{\text { Total Beban Pajak Penghasilan }}{\text { Laba Sebelum Pajak }}
$$

\section{Thin Capitalization}

Thin capitalization adalah pembentukan struktur modal perusahaan dengan kombinasi kepemilikan hutang yang banyak dan modal yang kecil. Variabel ini diukur menggunakan Debt to Equity Ratio (DER) yaitu rasio jumlah utang terhadap jumlah modal. 
Pengukuran Thin Capitalization(Wati \& Utomo, 2020) adalah:

IJI:R $\quad \begin{aligned} & \text { l Jtang } \\ & \text { Modal }\end{aligned}$

\section{Profitabilitas}

ROA memiliki keterkaitan dengan laba bersih perusahaan dan pengenaan pajak penghasilan untuk perusahaan. Semakin tinggi profitabilitas perusahaan akan semakin tinggi pula laba bersih perusahaan yang dihasilkan. Teori agensi akan memacu para agent untuk meningkatkan laba perusahaan. Ketika laba yang diperoleh membesar, maka jumlah pajak penghasilan akan meningkat sesuai dengan peningkatan laba perusahaan sehingga kecenderungan untuk melakukan tax avoidance yang dilakukan oleh perusahaan akan meningkat (Dewi \& Noviari, 2017). Secara matematis ROA dirumuskan sebagai berikut :

\section{Ukuran Perusahaan}

$$
\text { ROA }=\frac{\text { Laba Setelah Pajak }}{\text { Total Asset }}
$$

Ukuran perusahaan merupakan skala untuk menentukan besar kecilnya perusahaan menurut berbagai cara, diantaranya adalah: total aset, log size, penjualan, kapitalisasi pasar dan lain-lain. Semakin besar perusahaan maka semakin besar total aset yang dimiliki. Ukuran perusahaan pada penelitian ini diukur dengan rumus (L. E. Putri, 2018).

\section{SIZE $=$ Ln (Total Aset)}

\section{Teknik Analisis}

Pada penelitian ini terdapat tiga pendekatan yang dapat dilakukan untuk mengestimasi model regresi dengan data panel, yaitu pendekatan Common Effect Model, Fixed Effect Model dan Random Effect Model. Untuk memilih model mana yang terbaik maka dibutuhkan uji sebagai berikut:

\section{Uji Chow}

Uji Chow bertujuan untuk menentukan model analisis data yang akan digunakan dalam penelitian dan digunakan untuk memilih diantara metode common effect model dan fixed effect model. Dari hasil probabilitas Cross-selection F jika lebih kecil dari 5\% makamenggunakan common effect model dan sebaliknya jika hasil menunjukan lebih besar dari 5\% maka yang digunakan fixed effect model. Jika hasil data panel menunjukan probabilitas Cross-selection $\mathrm{F}$ lebih besar dari nilai 5\%,makafixed effect model yang dipilih untuk digunakan penelitian.

\section{Uji Hausman}

Uji hausman digunakan untuk menentukan pilihanantara metode fixed effect model dan random effect model. Apabila nilai p-value lebih kecil dari 5\% maka menggunakan fixed effect model, sedangkan lebih besar dari 5\% menggunakan random effect model.Dari hasil olah data panel nilai p-value cross selection random lebih besar dari nilai 5\%, dapat disimpulkan bahwa random effect model yang digunakan dalam penelitian ini.

\section{HASIL DAN PEMBAHASAN}

\subsection{Hasil penelitian}

Uji Statistik Deskriptif

Berdasarkan uji statistika deskriptif, dapat disimpulkan bahwa:

Tabel 1. Uji Statistik Deskriptif

\begin{tabular}{lccrr}
\hline & ETR & TCAP & ROA & \multicolumn{1}{l}{ SIZE } \\
\hline Mean & 0.308841 & 1.495362 & 0.393913 & 16.40203 \\
Median & 0.270000 & 1.020000 & 0.330000 & 16.14000 \\
Maximum & 0.840000 & 6.990000 & 0.820000 & 18.46000 \\
Minimum & 0.140000 & 0.220000 & 0.100000 & 13.99000 \\
Std. Dev. & 0.122577 & 1.267690 & 0.237692 & 1.289228 \\
Skewness & 1.984686 & 1.944715 & 0.443295 & -0.04723 \\
Kurtosis & 7.552925 & 7.817568 & 1.722603 & 1.753991 \\
Jarque-Bera & 104.8945 & 110.2178 & 6.951131 & 4.489199 \\
Probability & 0.000000 & 0.000000 & 0.030944 & 0.105970 \\
& & & & \\
Sum & 21.31000 & 103.1800 & 27.18000 & 1131.740 \\
Sum Sq. Dev. & 1.021707 & 109.2785 & 3.841843 & 113.0233 \\
& & & & \\
Observations & 69 & 69 & 69 & 69 \\
Cross sections & 23 & 23 & & 23 \\
\hline Sur : Olah & & & &
\end{tabular}

Sumber : Olah data eviews 10 
Penghindaran Pajak. Nilai ETR objek penelitian sangat bervariasi dengan nilai minimum ETR 0.14\%; PT Sri Rejeki Isman Tbk pada tahun 2019, nilai maksimum ETR sebesar $0.84 \%$ yaitu PT Lion Metal Works Tbk pada tahun 2019.

Thin Capitalization.Nilai minimum pada thin capitalization sebesar $0.22 \%$ dimiliki oleh PT Tembaga Mulia Semanan Tbk pada tahun 2019, nilai maksimum sebesar $6.99 \%$ yang dimiliki oleh PT Charoen Pokphand Indonesia Tbk pada tahun 2019.

Profitabilitas. Nilai minimum pada profitabilitas sebesar $0.10 \%$ yang dimiliki oleh PT Tembaga Mulia Semanan Tbk pada tahun 2019, dan nilai maksium sebesar $0.82 \%$ dimiliki oleh PT Garuda Metalindo Tbk pada tahun 201 .

Ukuran Perusahaan.Nilai minimum pada ukuran perusahaan sebesar $13.99 \%$ yang dimiliki oleh PT Garuda Metalindo Tbk pada tahun 2017, sedangkan nilai maksimum sebesar $18.46 \%$ dimiliki oleh PT Charoen Pokphard Indonesia Tbk pada tahun 2017.

\section{Analisis Regresi Data Panel}

Tabel 2.Hasil Dari REM

Variable Coefficient Std. Error t-Statistic Prob.

\begin{tabular}{lrrrr}
\hline \hline C & 1.024880 & 0.310494 & 3.300803 & 0.0016 \\
TCAP & 0.019457 & 0.012338 & 1.576965 & 0.1197 \\
ROA & 0.248078 & 0.096870 & 2.560931 & 0.0128 \\
SIZE & -0.039472 & 0.017017 & -2.319483 & 0.0235 \\
\hline
\end{tabular}

Sumber: Olah data eviews 10

Pada kolom coefficient menunjukan bahwa tanpa adanya pengaruh apapun, penghindaran pajak tetap mengalami kenaikan sebesar $1.24 \%$. Setiap kenaikan $1 \%$ pada thin capitalization, penghindaran pajak akan mengalami kenaikan sebesar $0.01 \%$. Setiap kenaikan $1 \%$ pada profitabilitas, penghindaran pajak akan mengalami kenaikan sebesar $0.24 \%$. Dan setiap kenaikan $1 \%$ pada ukuran perusahaan, penghindaran pajak mengalami penurunan sebesar $0.03 \%$.

Koefisien Determinasi. Angka adjusted RSquare sebesar 0.085755 menunjukan bahwa $85 \%$ perubahan ETR dapat dijelaskan oleh perubahan thin capitalization, profitabilitas dan ukuran perusahaan yang merupakan variabel bebas dalam penelitian ini. Sedangkan sisanya sebesar $15 \%$ perubahan ETR dijelaskan oleh variabel lain diluar model penelitian ini.
Uji F. Nilai probabilistic F-statistic 0.031686 lebih kecil dari significance level 0,05 yang menunjukan bahwa secara bersama-sama variabel bebas dalam penelitian ini dapat mempengaruhi ETR secara signifikan.

\subsection{Pembahasan}

\section{Pengaruh thin capitalization terhadap penghindaran pajak}

Berdasarkan hasil pengujian olah data panel menunjukan bahwa hasil koefisien regresi $\mathrm{X}_{1}$ 0.019457 yang nilai positif dengan probabilitasnya 0.1197 ,yang berarti bahwa $0.1197>0,05$. Hal tersebut berarti bahwa thin capitalization tidak berpengaruh terhadap penghindaran pajak. Thin capitalization merupakan tingkat utang yang dilakukan oleh perusahaan sebagai pembiayaan, jika perusahaan menggunakan utang maka akan timbul beban bunga yang harus dibayar oleh perusahaan. Keputusan pendanaan perusahaan ( pendana internal dan ekternal) dapat dijadikan gambaran mengenai penghindaran pajak. Namun, beban bunga yang dapat digunakan sebagai pengurang laba kena pajak yaitu yang muncul akibat pinjaman pihak ke tiga, dimana pihak ketiga tidak memiliki hubungan apapun terhadap perusahaan.

Jika dikaitkan dengan teori agensi, perusahaan menggunakan hutang untuk meningkatkan kinerja perusahaan. Laba yang besar menunjukkan kinerja perusahaan yang baik. Laba yang besar dapat menarik investor, sesuai dengan keinginan prinsipal. Hal ini dapat mengurangi konflik keagenan. Hasil penelitian ini sejalan dengan (Wati \& Utomo,2020), (Olivia \& Dwimulyani, 2019), (Komariah ,2017), yang membuktikan bahwa thin capitalization tidak berpengaruh terhadap penghindaran pajak. Namun, penelitian ini bertolak belakang dengan peneliti Widodo et al.,(2020) dan Falbo \& Firmansyah, (2018) yang menyatakan bahwa thin capitalization berpengaruh positif dan signifikan terhadap penghindaran pajak. Sedangkan penelitian yang dilakukan oleh Andawiyah et al., (2019) menyatakan bahwa thin capitalization berpengaruh negatif dan signifikan terhadap penghindaran pajak.

\section{Pengaruh profitabilitas terhadap penghindaran pajak}

Berdasarkan hasil pengujian olah data panel menunjukan bahwa hasil koefisien regresi $\mathrm{X}_{2}$ 0248078 yang nilai positif dengan probabilitasnya $0.0128<0,05$. Hal ini dapat dinyatakan bahwa 
profitabilitas berpengaruh positif signifikan terhadap penghindaran pajak. Perusahaan dengan profitabilitas tinggi memiliki kesempatan memposisikan dirinya dengan cara merencanakan pajak, sehingga dapat mengurangi jumlah beban pajak. Perusahaan dengan perencanaan pajak yang baik akan memperoleh pajak yang optimal, sehingga kecenderungan perusahaan untuk melakukan penghindaran pajak akan menurun.

Jika dikaitkan dengan teori agensi akan memacu para agen untuk meningkatkan laba perusahaan sehingga jumlah pajak penghasilan akan meningkat sesuai dengan peningkatan laba perusahaan. Laba perusahaan yang diukur dengan rasio profitabilitas menunjukan kinerja dari manajemen,Apabila rasio profitabilitas tinggi, berarti menunjukkan adanya efisiensi yang dilakukan oleh pihak manajemen dan tindakan efisiensi tersebut mengurangi nilai efektif tax rate.Penelitian ini sejalan dengan Hutapea \& Herawaty, (2020), Saputra et al., (2019) dan Olivia \& Dwimulyani, (2019) yang menyatakan bahwa pfitabilitas berpengaruh positif signifikan terhadap penghindaran pajak. Namun, pernytaan ini bertolak belakang dengan peneliti Jamaludin, (2020) yang menyatakan bahwa profitabilitas tidak berpengaruh terhadap penghindaran pajak. Sedangkan peneliti Dwiyanti \& Jati, (2019) menyatakan bahwa profitabilitas berpengaruh negatif signifikan terhadap penghindaran pajak.

\section{Pengaruh ukuran perusahaan terhadap penghindaran pajak}

Berdasarkan hasil pengujian olah data panel menunjukan bahwa hasil koefisien regresi $\mathrm{X}_{3}$ 0.039472 yang nilai negatif dengan probabilitasnya $0.0235<0.05$. hal ini dapat dinyatakan bahwa ukuran perusahaan berpengaruh negatif signifikan terhadap penghindaran pajak.Semakin besar total aset perusahaan menunjukkan perusahaan memiliki kinerja yang baik, perusahaan yang termasuk dalam kategori perusahaan berskala besar cenderung memiliki sumber daya untuk melakukan pengelolaan pajak yang lebih besar dibandingkan perusahaan kecil.

Jika dikaitkan dengan teori agensi, ukuran perusahaan merupakan suatu tolak ukur yang digunakan oleh pihak prinsipal dalam melakukan kegiatan investasi. Semakin besar aset suatu perusahaan maka menunjukkan perusahaan dapat mengelola aset dengan baik. Semakin tinggi aset dapat meningkatkan laba perusahaan. Laba yang tinggi mampu menarik perhatian investor. Pihak agen akan berusaha untuk mendapatkan laba agar pihak prinsipal tidak merasa dirugikan setelah melakukan investasi.Penelitian ini selajan dengan Putri, (2018) dan Sutono, (2020) menyatakan bahwa ukuran perusahaan berpengaruh negatif signifikan terhadap penghindaran pajak. Namun, penelitian ini bertolak belakang dengan Wulandari \& Masqudi, (2019) dan Putri et al., (2019) yang menyatakan bahwa ukuran perusahaan tidak berpengaruh terhadap penghindaran pajak.

\section{KESIMPULAN}

Peneliti yang telah dilakukan ini dengan menguji faktor-faktor yang mempengaruhi penghindaran pajak. Hasil pembahasan penelitian ini menyatakan sebagai berikut: 1).thin capitalization tidak berpengaruh terhadap penghindaran pajak, 2).profitabilitas berpengaruh positif signifikan terhadap penghindaran pajak, dan 3).ukuran perusahaan berpengaruh negatif signifikan terhadap penghindaran pajak.

Berdasarkan hasil penelitian yang telah dilakukan, dapat memberikan gambaran agar perusahaan dapat menyusun perencanaan pajak yang baik sehingga perusahaan terhindar dari indikasi penggelapan pajak. Penelitian selanjutnya diharapkan dapat menambahkan variabel lain sebagai factor penguat terjadi penghindaran pajak.Selain menambah variabel juga diharapkan menambahkan periode pengamatan dan sector perusahaan yang diamati

\section{UCAPAN TERIMAKASIH}

Puji syukur kehadirat Allah SWT yang memberikan rahmat dan hidayah-Nya sehingga penulis dapat menyelesaikan Tugas Akhir ini dengan lancar. Penulis hanya bisa mengucapkan banyak terimakasih kepada semua pihak yang telah membantu, diantaranya sebagai berikut :

a. Bapak dan Mamak tercinta yang selalu memberi dukungan dan doa yang terbaik.

b. Ibu Rachmawati Meita Oktaviani, S.E, M.Si., Ak.CA, Asean CPA selaku dosen pembimbing yang telah sabar dan telaten membantu saya dalam pembuatan tugas akhir.

c. Kakak- kakak tingkat yang telah membantu saya setiap kesulitan yang saya hadapi.

d. Adek saya yang telah mensuport saya.

e. Semua pihak yang membantu dan memberi dukungan. 


\section{REFRENSI}

Andawiyah, A., Subeki, A., \& Hakiki, A. (2019). Pengaruh Thin Capitalization Terhadap Penghindaran Pajak Perusahaan Index Saham Syariah Indonesia. Akuntabilitas, 13(1). https://doi.org/10.29259/ja.v13i1.9342

Dewi, N. L. P. P., \& Noviari, N. (2017). Pengaruh Ukuran Perusahaan, Leverage , Profitabilitas Dan Corporate Social Responsibility Terhadap Penghindaran Pajak ( Tax Avoidance ). E-Jurnal Akuntansi Universitas Udayana, 21, 830-859.

Dwiyanti, I. A. I., \& Jati, I. K. (2019). Pengaruh Profitabilitas, Capital Intensity, dan Inventory Intensity pada Penghindaran Pajak. E-Jurnal Akuntansi Universitas Udayana, 27, 2293-2321.

Falbo, T. D., \& Firmansyah, A. (2018). Thin Capitalization, Transfer Pricing Aggresiveness, Penghindaran Pajak. Indonesia Journal of Accounting and Governance, 2(June).

Hutapea, I. V. R., \& Herawaty, V. (2020). Pengaruh Manajemen Laba, Leverage dan Profitabilitas terhadap Tax Avoidance dengan Ukuran Perusahaan sebagai Variabel Moderasi. Prosiding Seminar Nasional.

Jamaludin, A. (2020). Pengaruh Profitabilitas (Roa), Leverage (Ltder) Dan Intensitas Aktiva Tetap Terhadap Penghindaran Pajak (Tax Avoidance) Pada Perusahaan Subsektor Makanan Dan Minuman Yang Terdaftar Di Bei Periode 20152017. Eqien: Jurnal Ekonomi Dan Bisnis, 7(1), 85-92. https://doi.org/10.34308/eqien.v7i1.120

Jumailah, V. (2020). Pengaruh Thin Capitalization dan Konservatisme Akuntansi terhadap Tax Avoidance dengan Kepemilikan Institusional sebagai Variabel Moderasi. Management \& Accounting Expose, 3(1), 13-21.

Komariah, N. (2017). Pengaruh Thin Capitalization Dan Karakter Eksekutif Dengan Konpensasi Manajemen Kunci Sebagai Pemoderasi Terhadap Penghindaran Pajak.

Oktaviani, R. M., Susanti, D. T., Sunarto, S., \& Udin, U. (2019). The Effect Of Profitability, Tax Avoidance And Information Transparency On Firm Value: An Empirical Study In Indonesia. International Journal of Scientific and Technology Research, 8(11), 3777-8780.

Olivia, I., \& Dwimulyani, S. (2019). Pengaruh Thin Capitalization dan Profitabilitas Terhadap Penghindaran Pajak dengan Kepemilikan Institusional sebagai Variabel Moderasi. Prosiding Seminar Nasional Pakar Ke 2: Sosial Dan Humaniora.
Putri, K. E., Sochib, \& Yahdi, M. (2019). Pebgaruh Intensitas Aset Tetap, Leverage, Return On Asset , Dan Ukuran Perusahaan Terhadap Penghindaran Pajak Pada Perusahaan Dagang Besar Yang Terdaftar di BursaEfek Indonesia. Progress Conference, 2(July).

Putri, L. E. (2018). Pengaruh Kepemilikan Institusional, Kepemilikan Manajerial, Preferensi Risiko Eksekutif, Leverage Dan Ukuran Perusahaan Terhadap Penghindaran Pajak. Director,

https://doi.org/10.22201/fq.18708404e.2004.3.6 6178

Rejeki, S., Wijaya, A. L., \& Amah, N. (2019). Pengaruh Kepemilikan Institusional Kepemilikan Manajeial dan Proporsi Dewan Komisaris Terhadap Penghindaran Pajak dan Transfer Princing Sebagai Variabel Moderasi (Studi Pada Perusahaan Manufaktur yang Terdafar di BEI Tahun 2014-2017. Seminar Inovasi Manajemen, Bisnis Dan Akuntansi.

Salwah, S., \& Herianti, E. (2019). Pengaruh Aktivitas Thin Capitalization Terhadap Penghindaran Pajak. Jurnal Riset Bisnis, 3(1), 30-36.

Saputra, M. D., Susanti, J., \& Istiarto. (2019). Pengaruh Profitabilitas, Kepemilikan Keluarga Dan Corporate Governance Terhadap Penghindaran Pajak Di Indonesia. Valid Jurnal Ilmiah, 16, 164-179.

Sutono, W. C. (2020). Pengaruh Corporate Governance Terhadap Tax Avoidance.

Wati, R. A., \& Utomo, R. B. (2020). Pengaruh Thin Capitalization Dan Kepemilikan Manajerial Terhadap Penghindaran Pajak.

Widodo, L. L., Diana, N., \& Mawardi, M. C. (2020). Pengaruh Multinasionalitas, Good Coorporate Governance, Tax Haven, Dan Thin Capitalization Terhadap Praktik Penghindaran Pajak Pada Perusahaan Multinasional Yang Terdaftar Di Bei Periode Tahun 2016-2018. EJra, 09(06), 119-133.

Wulandari, Y., \& Masqudi, A. (2019). Pengaruh Ukuran Perusahaan, Leverage, Dan Pertumbuhan Penjualan Terhadap Penghindaran Pajak Dengan Profitbilitas Sebagai Variabel Intervening Pada Perusahaan Manufaktur Sektor Food \& Beverage Yang Terdaftar Di BEI Periode 2014-2018. Jurnal Ekonomi Akuntansi, 4, 35-50. 